\title{
Antalya anıt ağaçlarının mekân ve anlam açısından değerlendirilmesi
}

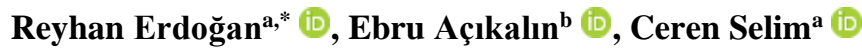

Özet: Bu makalede, Antalya ilinde bugüne kadar tespit edilen anıt ağaçlara ait bazı bilgiler verilmiş ve 12 anıt ağaç tanıtılmıştır. Araştırma alanında yapılan tespitlere bakıldığında, Toros sediri (Cedrus libani A. Rich), Boylu ardıç (Juniperus excelsa Bieb.), Doğu çınarı (Platanus orientalis L.) ve Anadolu kestanesi (Castanea sativa) türlerinden oluşan anıt ağaçların, bulundukları, yer, yaş, boy gibi fiziksel özellikler ve anlam açısından değerlendirmelere yer verilmiştir. Çalışmada anıt ağaçların doğa ve ağaç duyarlılığının arttırılmasında öğrencilere eğitici gezi ve uygun mekanlar oluşturarak katk1 koyabilmesi yönünde öneriler sunulmuştur.

Anahtar kelimeler: Antalya, Anıt ağaç, Ardıç, Sedir, Çınar, Kestane

\section{Evaluation of monument trees of Antalya in terms of space and meaning}

\begin{abstract}
In this article, some information was given about monumental trees detected in Antalya so far and 12 of them were introduced. When we look at the findings, the physical characteristics such as height, age, location and meaning of monumental trees consisting of Taurus cedar (Cedrus libani A. Rich), tall juniper (Juniperus excelsa Bieb.), Eastern plane (Platanus orientalis L.) and Anatolian chestnut (Castanea sativa) were evaluated. Suggestions were made for the students to contribute to the increase of nature and tree sensitivity of monumental trees by creating educational trips and suitable spaces.

Keywords: Antalya, Monumental tree, Juniper, Cedar, Plane, Chestnut
\end{abstract}

\section{Giris}

Ağaçlar geçmişten günümüze değin bir kült simgesi olarak kabul edilmiştir. Antik Yunan çağından modern çağa kadar hayatın devamlılığının ve kozmik gücün simgesi olarak algılanmış ve bu bağlamda ağaca duyulan saygı, kesintisiz devam etmiştir (Pardo, 2005). Güzellik, cesaret, direnç ve yaşamın temel gücü olarak görülmesi evrensel bir değer olarak paylaşılmıştır (Musselman, 2003; Albian ve Berwick, 2004). Çeşitli toplumlar ağaçlardan büyülü totemler yaratmışlardır. Bazı özel nitelikli ağaçlar, "azizlik" ve "peygamberlik" sıfatları ile kutsallaştırılmıştır (Séne, 2003). Bazı medeniyetlerde, yazılarda kullanılan harfler ağaçlardan seçilmiştir. Baltık alfabesinin (Ogham) 25 karakteri, 20 ağaç ve bazı kutsal bitkilerden oluşur. İrlanda kültüründe de kayın ağacının odunundan eski yazı takımlarının yapımında yararlanılmış, ağacın ince kabukları da ilk kitapların sayfaları olarak kullanılmıştır. Nitekim İngilizce ve diğer bazı HintAvrupa dillerinde kitap (book) kelimesi ile kayın kelimesi (beech) etimolojik olarak birbirine bağlıdır (Crews, 2003). Ağaçlar ve ormanlarla ilgili tabu, ayin ve inançlarla desteklenen ve kuşaktan kuşağa aktarılan mistik folklor, dinler ve geleneklerdeki ağaç sevgisinin temelini oluşturmaktadır (Swamy vd., 2003; Garcia vd., 2006). İncil'de ağaç ve ormana yapılan atıf sayısının 525 olduğu bilinmektedir. $\mathrm{Bu}$, insandan sonra tüm canlı varlıklar içindeki en yüksek atıf sayısıdır (Musselman, 2003). İslam dininde ağaç sevgisine büyük önem verilmiştir. Kur'an-1 Kerim'in en az 50 ayetinde doğanın araștırılması önerilmektedir. İslam'da doğanın araştırılması ibadete eşdeğer sayılmıştır (Tez, 2008).

Genel olarak ağaçlar nesiller boyu böylesine önemliyken, anıt ağaçlar, tarihe tanıklık eden uzun ömürleri ve devasa yapıları ile dünyamızın ayrıcalıklı varlıklarıdır. Bu devasa ağaçların, bazen 1000'lerle ifade edilen yaşları ile geçmişten günümüze taşıdıkları kültürel miras ve sürekli gelişimleri sonucu değişen fiziksel özellikleri, toplumu etkileyerek benliğinde özel bir yer almalarını sağlar. Bu etki, insanların soya, ulusa ve bulunduğu yöreye bağlığını artırırken, diğer yandan toplumda doğa sevgisi ve çevre bilincinin artmasına önemli katkılar sağlamaktadır (Asan, 2010).

Ülkemizdeki ilk anıt ağaç betimlemeleri Evliya Çelebinin (1611-1682) ünlü seyahatnamelerinde geçmektedir. Evliya Çelebinin "ibret alınacak ağaçlar" kavramını kullanarak ayrıntılı biçimde anlattı̆̆ 1 bu ağaçlar, günümüzde Tavas ile Muğla arasındaki bir bölge olarak bilinmektedir. Çelebinin kayıt altına aldığı bu ağaçlar, tarihimizde kayıtlara geçen ilk 10 anıt ağaç (bunlara farklı yöreden 2 tane de daha ekleme yapmıştır) olarak da kabul edilir (Baytop, 2003).

"Yaş, çap ve boy itibarıyla kendi türünün alışılagelmiş ölçüleri üzerinde boyutlara sahip olan, yöre folklorunda, kültür ve tarihinde özel yeri bulunan, geçmiş ile günümüz, günümüz ile gelecek arasında iletişim sağlayabilecek uzunlukta doğal ömre sahip olan ağaçlar" bilimsel olarak anıt ağaç olarak tanımlanmaktadır (Asan,1991; Asan, 1993).

Özellikle ağacın çapı ve boyu gibi fiziksel özellikleri bir ağacı anıt yapan özelliklerin başında gelir. Ağaç yaşının

\footnotetext{
凹 a Akdeniz Üniversitesi, Mimarlık Fakültesi, Peyzaj Mimarlı̆̆ Bölümü, Antalya

b Antalya Büyükşehir Belediyesi, Park ve Bahçeler Şube Müdürlüğü, Antalya

@ * Corresponding author (İletişim yazarı): reyhanerdogan@akdeniz.edu.tr

$\checkmark \quad$ Received (Geliş tarihi): 08.02.2021, Accepted (Kabul tarihi): 08.08.2021
}

Citation (Atıf): Erdoğan, R., Açıkalın, E., Selim, C., 2021. Antalya anıt ağaçlarının mekân ve anlam açısından değerlendirilmesi. Turkish Journal of Forestry, 22(3): 342-352. DOI: $\underline{10.18182 / \mathrm{tjf} .876715}$ 
hatalı tahminlerinden kaçınmak için dendrokronoloji veya bu mümkün olmadığında radyo karbon tarihlendirmesi (Karbon14 yöntemi) gibi bilimsel yöntemler kullanılmalıdır (Bernabei, 2015). Ancak sadece fiziksel özellikleri bir ağacı anıtlaştırmak için yeterli değildir. Anıt ağaçların, fiziksel özellikleri yanında kuşaklar arasında bağ kurabilecek uzunlukta doğal ömre de sahip olması gerekir. Bulunduğu yörenin kültüründe gerçek veya hayal, olumlu veya olumsuz, mistik veya folklorik bir öyküsü olan, tarihte kimi olaylar ile özleştirilmiş olmaları ve tarihe tanıklık etmiş olmaları da bu ağaçlara anıtsal nitelik kazandırmıştır. İşte bu nedenledir ki, anıt ağaçlar sahip oldukları bu özelliklerden dolayı her türlü önlemler alınarak mutlak koruma altına alınması, hiçbir gerekçe ile kesilmemesi, bir başka yere taşınmaması ve gelecek nesillere doğal miras olarak bırakılması gereken ağaçlardır. Anıt ağaçlar boyutsal ve kültürel özelliklerine göre tescil edilerek; boyutsal, tarihi, folklorik, mistik olmak üzere 4 gruba ayrılır (Bayar vd., 2012):

1-Boyutsal Anıt Ağaçlar: Yaş, boy, gövde ve tepe çap1 gibi boyutsal özellikleri bakımından aynı tür içinde veya benzer yetişme ortamlarında alışllagelmiş ölçülerinin çok üzerindeki boyutlara ulaşmış ağaçlardır.

2- Tarihi Anıt Ağaçlar: Tarihî bir olaya veya şahsiyete ait geçmişe tanıklık etmiş olan ağaçlardır.

3- Folklorik Anıt A ğaçlar: Halk kültüründe geleneksel bir kıymeti olan, yörede yaşanan çok üzücü veya sevindirici bir olaya tanıklık ettiği için halk arasında özel yeri olan ağaçlardır.

4- Mistik Anıt A ğaçlar: Dini bir inanışa göre yöre halk1 tarafından yüceltilmiş olan ağaçlardır. Şaman, Türk ve Orta Asya mitolojisinde ağaçlar kutsal sayılmıştır. İnsanlar tarih boyunca, ulu ağaçları tanrılaştırmış ve tapmışlardır.

\section{Materyal ve yöntem}

Alanya'dan Kaş'a kadar uzanan Antalya ili, Türkiye'nin en boylu ve sayı olarak en fazla anıt ağaçlarını barındırması açısından oldukça önemlidir.

$\mathrm{Bu}$ makalede yöresel olarak birbirinden çok farklı özelliklere sahip Antalya'nın farklı bölgelerini temsil eden altı yörede yer alan simgesel nitelikleri olan en önemli 12 tescilli anıt ağacı materyal olarak içermiştir (Şekil 1). Bu ağaçlar, Antalya'nın ilçeleri olan Kaş, Elmalı, Kumluca, Kemer, Korkuteli ve Akseki'deki anıt ağaçlardır.

Ağaçların mekanlar için önemini ve insan ile ağaç arasındaki derin ilişkiyi araştıran Cihanger (2013), bu iliş̧kiyi Yapı (Mekandaki Konumsal Dağılım), Aktivite (Aktivite tipleri-Ziyaretçilerin alana gelme nedeni ve ziyaretçi sayısı), Anlam (Mekan ve Ağaçların anlamı) olmak üzere 3 ana başlık altında toplamıştır. Bu çalışmada belirlenen anıt ağaçların kırsal alanda ve yapısal ögelerden uzakta bulunması nedeniyle yap1 konusu ihmal edilerek aktivite ve anlam açısından değerlendirilmiştir. $\mathrm{Bu}$ kapsamda anıt ağaçlar konum, erişilebilirlik, güvenlik, donatı varlığı, görsel kalite ve çevre ile ilişki açısından değerlendirmeye alınmıştır. Değerlendirme sonucunda anıt ağaçlar için uygulamaya yönelik öneriler geliştirilmiştir.

\section{Bulgular}

Tarım ve Orman Bakanlığı Doğa Koruma ve Milli Parklar Genel Müdürlüğü ve Çevre ve Şehircilik Bakanlığı Tabiat Varlıklarını Koruma Genel Müdürlüğü tarafindan tescil edilmiş 161 anıt ağacın yanında, Antalya'da anıt ağaç niteliğinde tescil edilmeyi bekleyen daha birçok ağaç mevcuttur. Çalışma kapsamında yedi tanesi Elmalı'da olmak üzere, Kemer, Kaş, Kumluca, Korkuteli ve Akseki ilçelerinden de 12 anıt ağaç incelenmiştir.

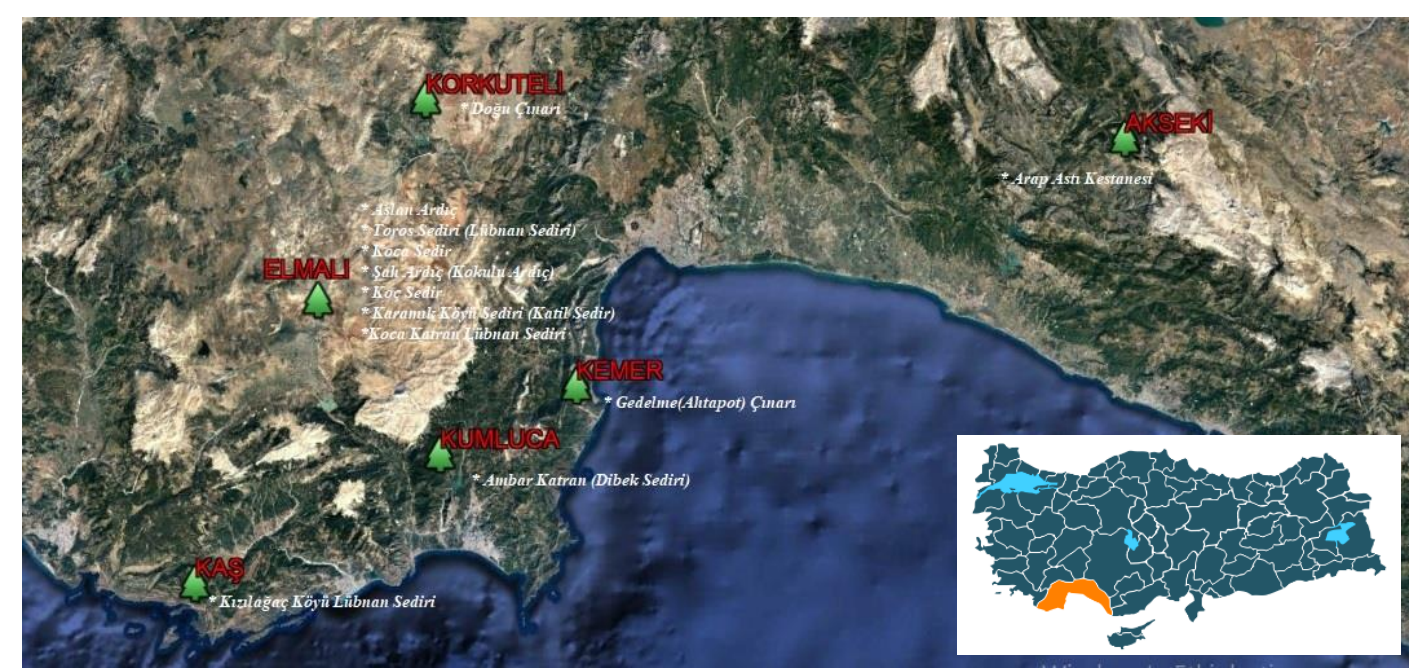

Şekil 1. Araştırma kapsamında ele alınan anıt ağaçlar (Orj., 2020) 


\subsection{Elmalı Yöresi}

Antalya'nın Elmalı ilçesi anıt ağaç bakımından oldukça önemlidir. Özellikle Elmalı-Finike sınırında yer alan Elmalı'ya 55 kilometre, Antalya'ya ise 165 kilometre uzaklıktaki 1000-2000 yaşlı ağaçların yer aldığı 15.889 hektarlık Çığlıkara Ormanı, nadide ağaçların yayılış alanı olup, ülkemizdeki sedir ormanlarının da \%30'una sahiptir. Halk arasında katran olarak nitelendirilen Toros sedirinin de en güzel yayılış alanı Beydağları üzerindeki Çığlıkara ve Çam Kuyuları Mevkiidir. Çığlıkara, sadece Türkiye'nin değil, tüm dünyanın en nadir sedir ormanlarından biridir. Ormanı oluşturan sedirler arasında ardıçlar da yer alır. Çığlıkara ormanında birçok ağaç 1995 yılında anıt ağaç olarak tescil edilmiştir.

Elmalı yöresinde bulunan 7 Anıt ağacın orman alanı içinde bulunması, orman bölge müdürlüğü izni dahilinde bu ağaçlar arasında bilimsel amaçlı bir anıt ağaç gezi rotası oluşturulmasını olanaklı kılmaktadır. Belli aralıklarla bilgilendirme panoları, her üç kilometrede bir mesafe belirten işaret levhaları ve anıt ağaçlar çevresinde uygun yerlerde ahşap oturma birimlerine yer verilmesi anıt ağaçların simgesel motivasyon kaynağı olarak doğa severler için farkındalık oluşturmada etkili olacağı düşünülmektedir.

\subsubsection{Aslan Ardıç (Juniperus foetidissimo)}

Elmalı ilçesi Tekke köyü Tekke Boğazı mevkiinde Çığlıkara Tabiatı Koruma Alanı'nda yer alan Arslan Ardıç, 21.04.1995 tarihinde tabiat anıtı ilan edilmiştir (Şekil 2) (TOB, 2020a; TOB, 2020b; Cengiz vd., 2007).

23,2 m boyunda, $3 \mathrm{~m}$ gövde çapında ve 9,52 m gövde çevresindeki Aslan Ardıç'ın yaşı yaklaşık 1700 olarak belirlenmiştir. M.S 395 yılına kadar Roma imparatorluğu egemenliğine, 395-1080 yılları arasında Doğu Roma (Bizans) imparatorluğu egemenliğine, 1080-1324 yılları arasında Doğu Roma imparatorluğu egemenliğine, 1324-1423 yılları arasında da Anadolu Selçuklu devleti egemenliğine tanıklık etmiş bir ağaçtır. Halk ozanı Abdal Musa'nın deyişlerinde yer almış bir ağaç olup, Alevilik kültüründe önemli bir yeri vardır. Mistik anıt ağaçlardandır (TOB, 2020a).

\subsubsection{Toros Sediri (Cedrus libani)}

Elmalı İlçesinde, 1995 yılında anıt ağaç ilan edilen ve Toros Sediri olarak da bilinen 1500 yıllık bu ağaç, Çığlıkara Tabiatı Koruma alanında yer alır. Kerestesinin yumuşaklığı, eşsiz kokusu ve dayanıklılığı ile kıymetli bir ağaçtır. 25 metre boyunda olan anıt ağaç, 262 santimetre çap ve 8 metre 23 santimetre çevre genişliğine sahip ve boyutsal anıt ağaçtır (KTB, 2020).

\subsubsection{Koca Sedir (Cedrus libani)}

Elmalı ilçesi Göltarla köyü, Ekizler, Alıçalanı mevkiinde Elmalı Sedir Araştırma Ormanı'nda yer alan Koca Sedir'in 2010 yılında 898 yaşında olduğu belirlenmiştir (Şekil 3). 32,5 m boyunda, 2,29 m gövde çapında ve 7,19 m gövde çevresinde olan Koca Sedir, 16.09.2002 tarihinde tabiat anıtı ilan edilmiştir. Milattan önceki çağlarda büyük medeniyetlere sahne olmuş, saray, mabet ve lüks yapıların inşasında kullanılmıştır. Gerek katranı gerekse odunu eski Mısır mumyacılığında kullanılmış bir ağaç türüdür. Koca Sedir, Anadolu Selçuklu Devleti ve Osmanlı imparatorluğunun tamamına tanık olmuş, 1927-1936 yılları arasında müteahhitlik kesiminde beğenilmeyip bırakılarak günümüze kalmış bir tarihi anıt ağaçtır (TOB, 2020a).

\subsection{4. Şah Ardıç (Juniperus foetidissimo)}

Elmalı İlçesi, Göltarla köyü, Işıkbeli mevkiinde Elmalı Sedir Araştırma Ormanı'nda yer alan Şah Ardıç 21.02.1995 tarihinde tabiat anıtı ilan edilmişstir (Şekil 4) (TOB, 2020a; TOB, 2020b; Cengiz vd., 2007).

22,8 $\mathrm{m}$ boyunda, 2,42 $\mathrm{m}$ gövde çapında, 7,46 $\mathrm{m}$ gövde çevresindeki Şah Ardıç, Anadolu Selçuklu devletinin son dönemi ile Osmanlı imparatorluğunun tamamına tanıklık etmiş bir ağaçtır. Elmalı dağlarına güzel kokmayı o öğrettiği için halk arasında "Kokulu Ardıç" denmektedir. Tahmini yaşı o zaman 989 olarak belirlenmiştir. Folklorik anıt ağaçtır (TOB, 2020a).
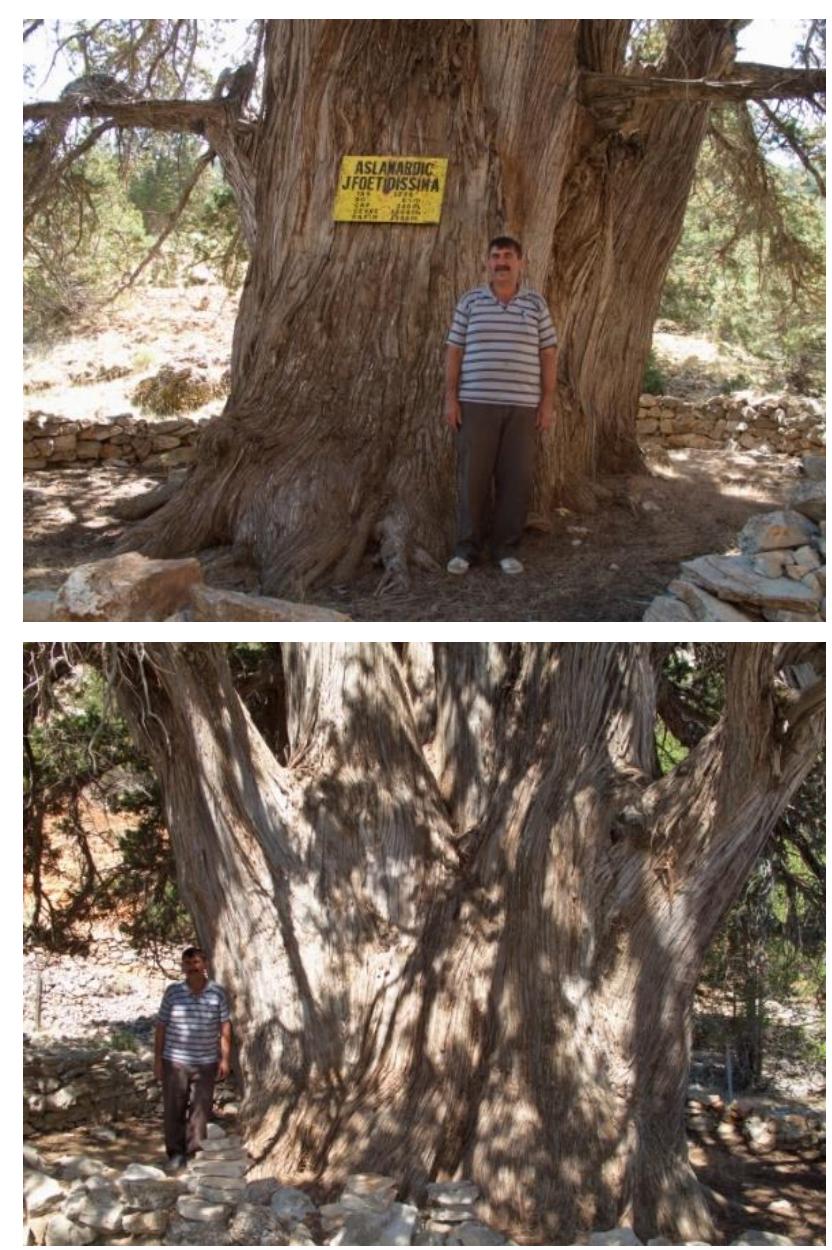

Şekil 2. Antalya ili Elmalı ilçesinde bulunan Aslan Ardıç (Foto: Ümit Durak) 

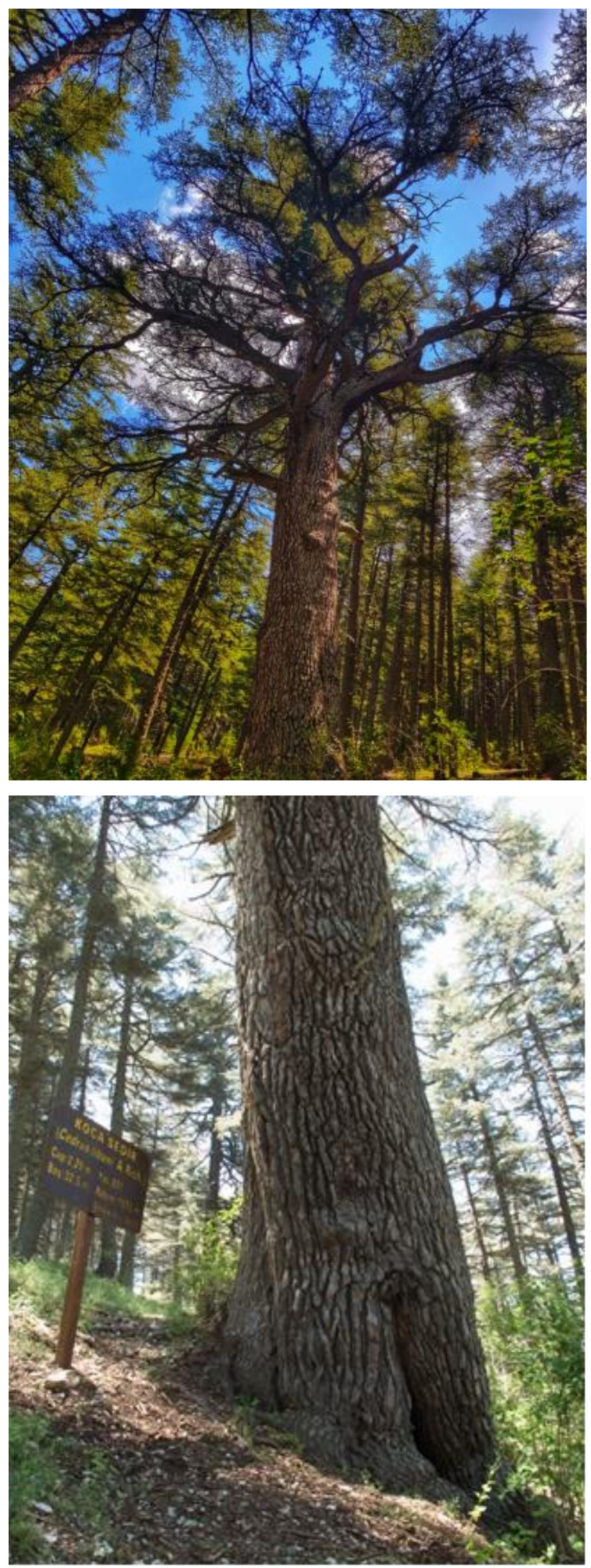

Şekil 3. Antalya ili Elmalı ilçesinde bulunan Koca Sedir (Foto: Tarım ve Orman Bakanlığı Milli Parklar Antalya Şube Müdürlügü Arşivi)
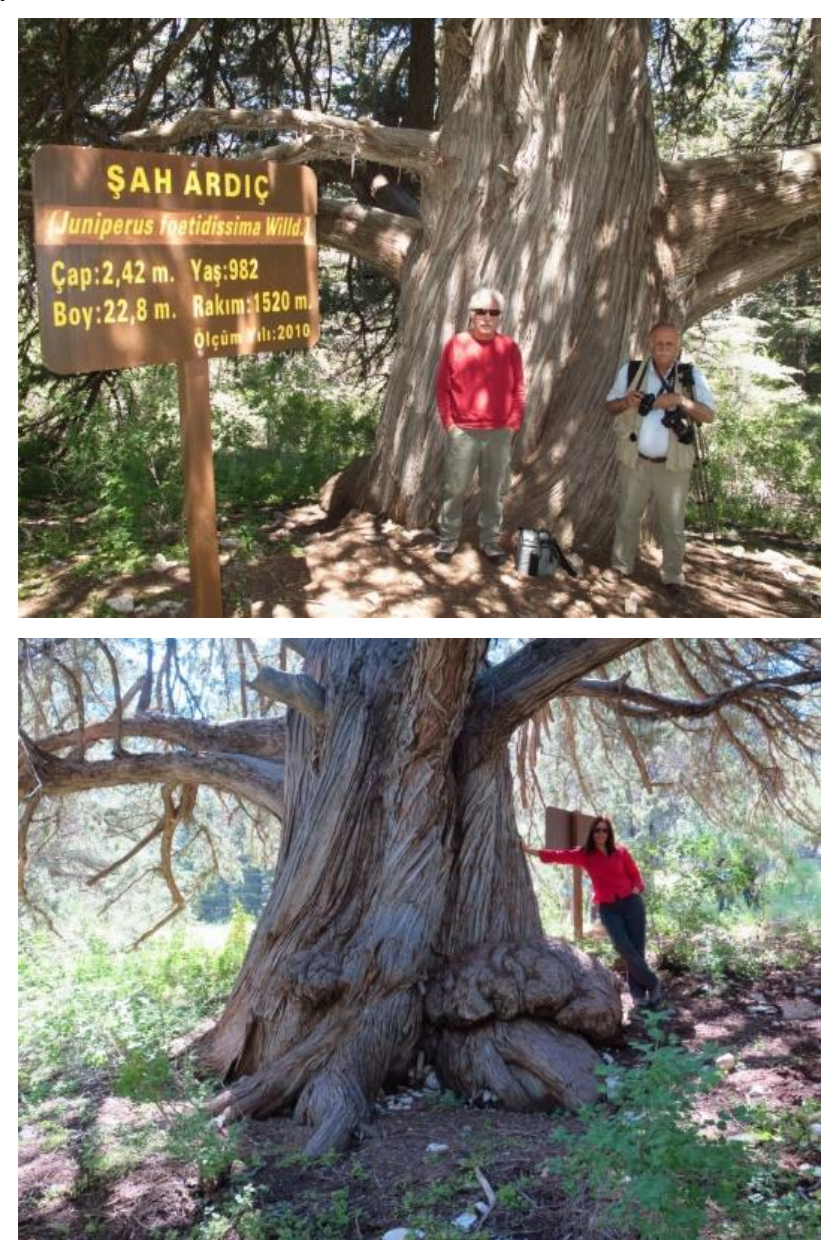

Şekil 4. Antalya ili Elmalı ilçesinde bulunan Şah Ardıç (Kokulu Ardıç) (Foto: Ümit Durak)

\subsubsection{Koç Sedir (Cedrus libani)}

Elmalı ilçesi Kızılağaç köyü Tavşanalanı mevkiinde Çı̆̆lıkara Tabiatı Koruma Alanı'nda olup bilimsel araştırmalar için kullanılan Koç Sedir 21.02.1995 tarihinde tabiat anıtı ilan edilmiştir (Şekil 5) (TOB, 2020a; TOB, 2020b; Cengiz vd., 2007).

Tahmini yaş1 680, gövde çapı 2 , uzunluğu ise 38 metredir. Anadolu Selçuklu Devleti son bulduktan sonra bir müddet Teke Beyliğine ve 1423 yılından sonra da Osmanlı imparatorluğuna tanıklık etmiş bir ağaçtır. İslam ve birçok dini inanışa göre kutsal kabul edilmiştir. Mistik anıt ağaçtır (TOB, 2020a). 

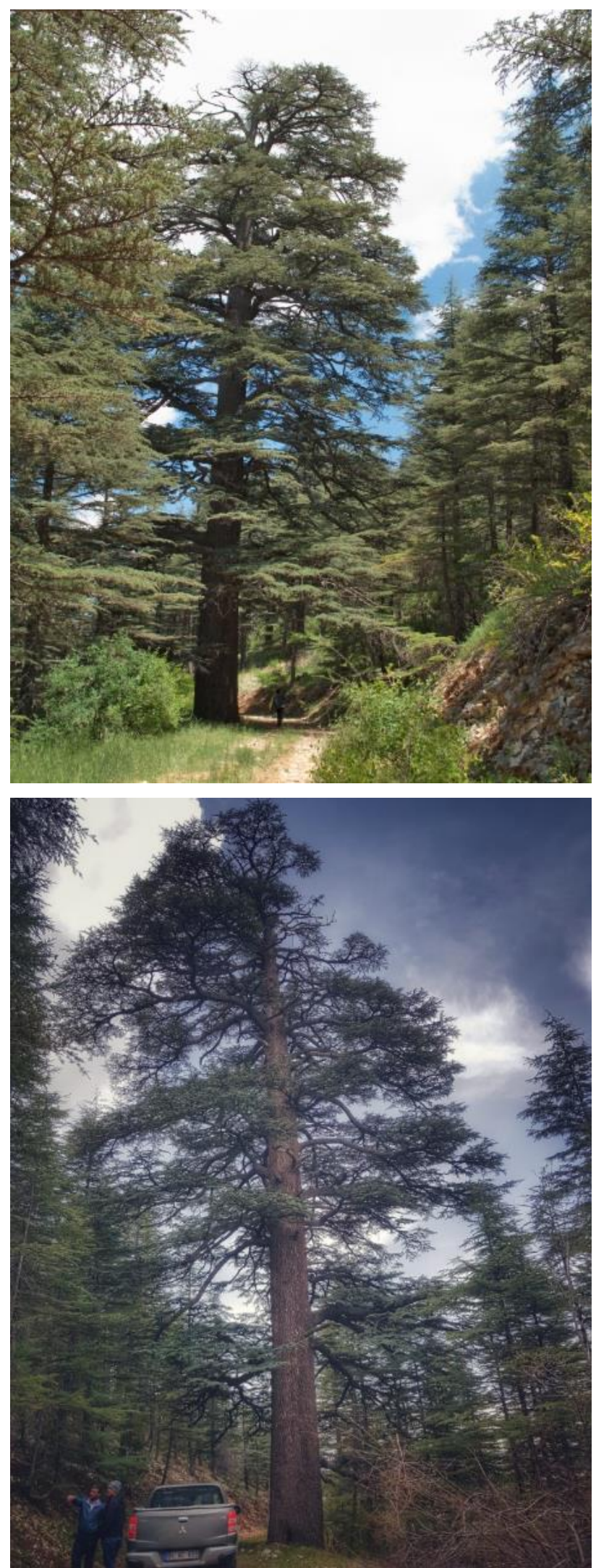

Şekil 5. Antalya ili Elmalı ilçesinde bulunan Koç Sedir (Ümit Durak)

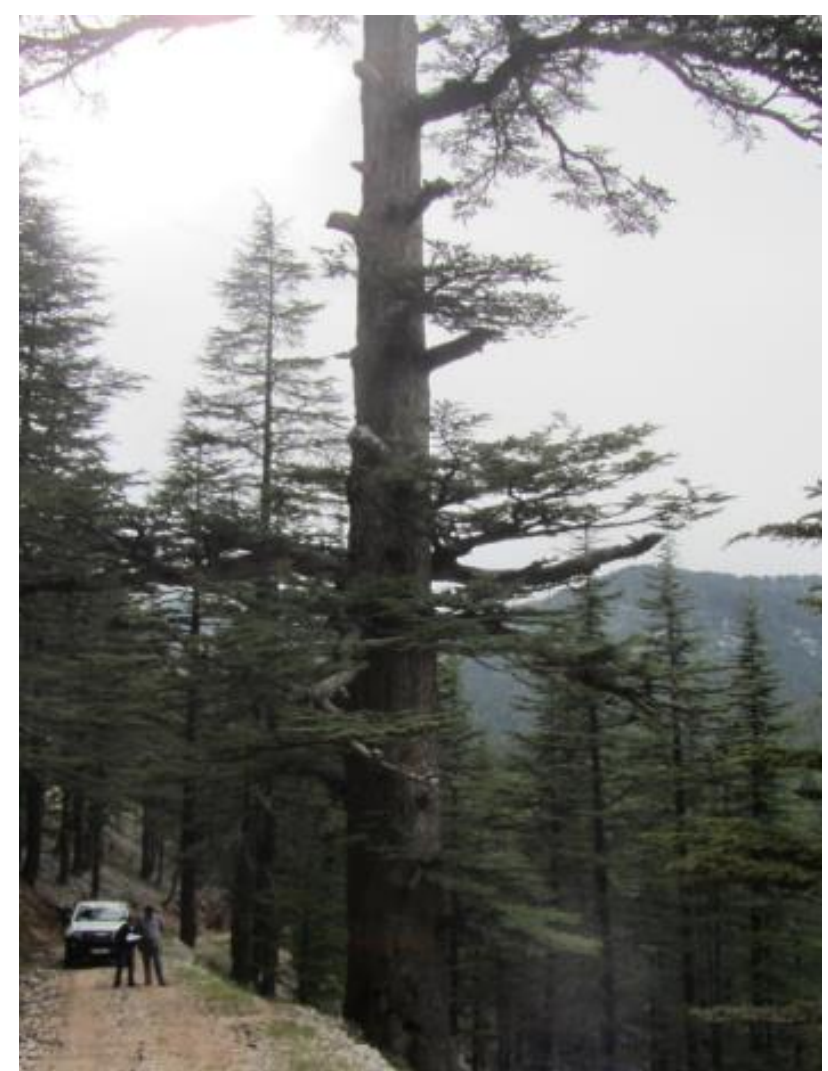

Şekil 6. Antalya ili Elmalı ilçesinde bulunan Karamık Köyü Sediri (Katil Sedir) (Ümit Durak)

\subsubsection{Karamık Köyü Sediri (Cedrus libani) (Katil Sedir)}

Elmalı ilçesi Karamık Köyü, Oluk Köprü, Suluçukur mevkiinde Çığlıkara Tabiatı Koruma Alanı'nda olup, 21.04.1995 tarihinde tabiat anıtı ilan edilmiştir (Şekil 6) (TOB, 2020a; TOB, 2020b; Cengiz vd., 2007).

Tahmini yaş1 672'dir. 26,5 m boyunda, $1,75 \mathrm{~m}$ gövde çapında, 5,5 m gövde çevresindeki bu ağaç 1352-1423 yılları arasında Teke beyliğine, 1423-1920 yılları arasında Osmanlı imparatorluğuna tanıklık etmiştir. Ağacın gövdesinde bulunan balı almak için çıkan iki kişi ağaçtan düşerek öldüğü için ağacın yöredeki adı "Katil Sedir" dir. Folklorik anıt ağaçtır. Ağacın bulunduğu bölge tabiatı koruma alanı olup bilimsel araştırmalar için kullanılmaktadır (TOB, 2020a).

\subsubsection{Koca Katran (Cedrus Libani)}

Elmalı ilçesi Doğantaş köyü, Bölükkatran mevkiinde Çı̆̆lıkara Tabiatı Koruma Alanı içerisinde yer alan Koca Katran 21.02.1995 tarihinde tabiat anıtı ilan edilmiştir (Şekil 7) (TOB, 2020a; TOB, 2020b; Cengiz vd., 2007).

Boyu 32,3 m, gövde çapı 2,53, gövde çevresi ise 7,97 m olarak belirlenmiştir. 1302-1324 yılları arasında Doğu Roma (Bizans) imparatorluğu egemenliğine, 1324-1423 yıllarında Teke beyliği egemenliğine, 1423-1920 Osmanlı imparatorluğu egemenliğine tanıklık etmiştir. İslam dini ve birçok dini inanışta kutsal kabul edilmiş bir ağaçtır. Mistik anıt ağaçtır. Ağacin bulunduğu bölge tabiatı koruma alanı olup bilimsel araştırmalar için kullanılmaktadır (TOB, 2020a). 


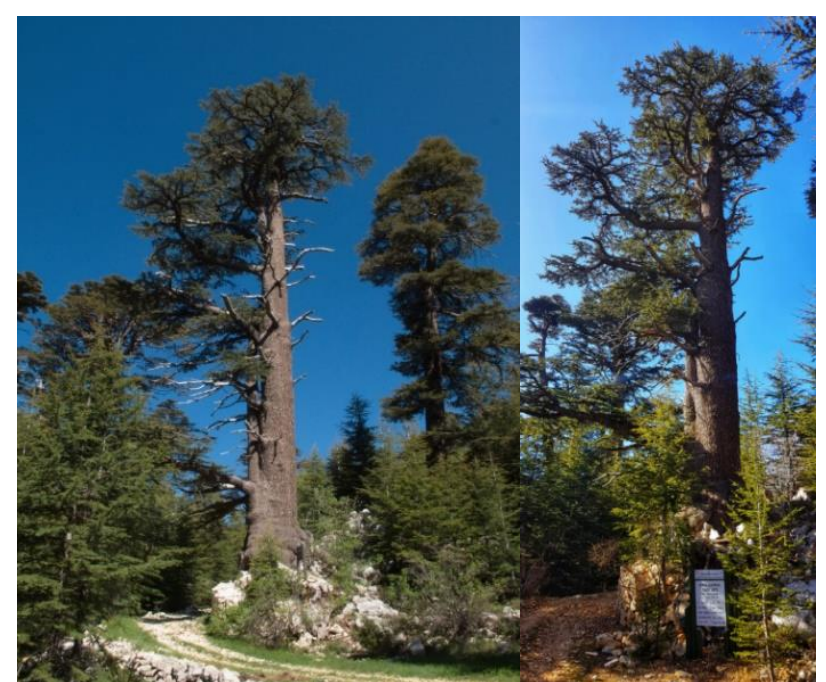

Şekil 7. Antalya ili Elmalı ilçesinde bulunan Koca Katran (Lübnan Sediri) (Ümit Durak)

\subsection{Kaş Yöresi}

Antalya'nın batısında, Akdeniz kıyısında turistik bir ilçedir. Kıyı uzunluğu 90 km.'dir. Toros dağlarının eteğinde, tarihi ve kültürüyle her yıl binlerce turist ağırlar.

\subsubsection{Kızılağaç Köyü Lübnan Sediri (Cedrus libani)}

Kaş İlçesi, Kızılağaç köyü, Gedik Çukuru mevkiinde, 21.02.1995 tarihinde tescil edilmiştir. 1500 yaşında olduğu tahmin edilmektedir (Cengiz vd., 2007). 26 metre boyunda, 2.45 metre gövde ve 7.69 metre taç genişliğine sahiptir (Acar, 2015). Oldukça sık bir orman dokusu içinde yer alan anıt ağaç, bulunduğu mekan itibariyle benzersiz bir etkiye sahiptir. Bazı yazarlara göre bu tarz bir orman, insanın, onun aracılığıyla, kendisini tanımasına ve çözümlemesine imkân veren metaforlarla yüklü simgesel bir yapıya sahiptir. Tüm bunların yanında orman, bazı Gerçeküstücü sanatçılar için bir nevi, uygarlıkla hesaplaşmanın metaforu olmuştur. Orman bilinçdışını harekete geçiren öğelerle kaplı, düşlere açık, gizemli ve büyülü bir alanı temsil etmektedir. Bu özelliğiyle Kaş'ın büyülü deniz, kum, güneş ve vazgeçilmez coğrafik güzelliklerine bir alternatif olarak, bu mekan oldukça ayrıcalıklıdır. Hiçbir mekânsal organizasyona izin vermez.

Eski çağlarda devletlerin zenginliğini ve gücünü sedir ağaçları ile kaplı ormanlardan olduğu söylenegelinir. Gençlikte piramidal bir tepeye sahip olan Lübnan sedirinin tepesi, yaşlandıkça şemsiye gibi bir hal alır. Ağaç yaşlandıkça boyuna çatlaklı, pullu bir yapıya, rengi de siyahımtırak kül rengine döner. Halk arasında siyah renkli zifte benzeyen reçinesinden dolayı "katran ağacı" olarak isimlendirilir. Görünümü ise heybetlidir. Bir tarih abidesi olarak adlandırılan Kızılağaç Köyü Lübnan Sediri tarihi anıt ağaçtır.

\subsection{Kumluca Yöresi}

İlçede; Olympos, Corydella, Rhodiapolis, İdebessiois, Gagae gibi önemli antik kentler bulunmaktadır. Özellikle, Olympos çok fazla yerli ve yabancı turist tarafindan ziyaret edilmektedir. İlçenin sahil şeridi $30 \mathrm{~km}$.'dir. Bu sahil şeridinde Çavuşköy Kasabası'ndaki Adrasan koyu ile
Olympos koyu; otel, motel, pansiyon ve restoranları ile yerli ve yabanc1 turistlere hizmet vermektedir.

\subsubsection{Ambar Katran (Cedrus libani)}

Antalya'nın Kumluca İlçesi Dibek Tabiatı Koruma Alanı'nda bulunan "Ambar Katran" ya da "Dibek Sedir" olarak adlandırılan sedir ağacı, 2326 yaşında, $25 \mathrm{~m}$ boyunda ve $2.62 \mathrm{~m}$ gövde çapında Türkiye'nin ve dünyanın en yaşlı sedir ağacıdır (Şekil 8) (Kantarcı, 1984). Tarihi anıt ağaçtır. 13.09.2002 tarihinde tabiat anıtı ilan edilmiştir (TOB, 2020a).

Ambar Katran'ın bulunduğu yer bir kuru dere vadisinin başlangıcıdır. Arazi çok eğimli olduğu için ağacın dibinde alt ve üst kısmı arasında 110 cm'lik bir yükseklik farkı vardır. Ağaç çevresinde teraslama yapılarak düzlük alanlar oluşturulabilir. Mekanı tanımlayıcı doğal sınır elemanlarıyla ağaçla fiziksel iletişimi kolaylaştıracak düzenlemeler yapilabilir.
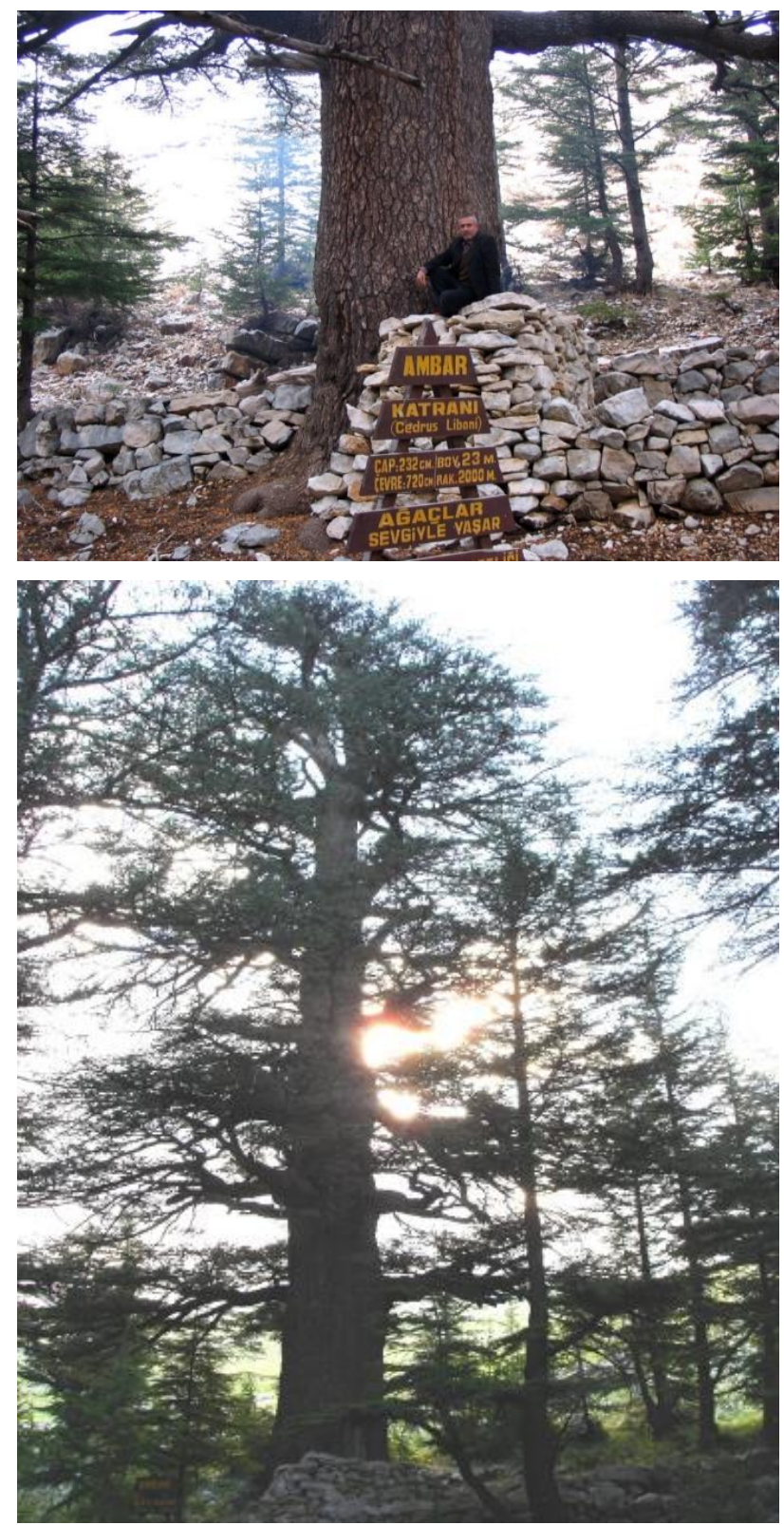

Şekil 8. Antalya ili Kumluca ilçesinde bulunan Ambar Katran (Dibek Sedir) (Ümit Durak)

3.4. Kemer Yöresi 
Antalya'nın batısında Akdeniz kıyısındaki turistik ilçelerden biri olan Kemer yerli ve yabancı turistler için deniz, kum ve güneş tatili için tercih edilen bir yöredir. Bu anlamda Kemer'in kırsalında yer alan anıt ağaç yakınında bulunan tarihi doku ile birlikte turistin ilgisini doğa ve kültüre çekme açısından oldukça önemlidir.

\subsubsection{Gedelme Çınarl (Platanus orientalis)}

İlçe merkezine 13 kilometre uzaklıktaki Kuzdere Köyü, 600 rakımlı Gedelme Yaylası'nda 06.05.2003 tarihinde tescil edilmiştir (Şekil 9) (TOB, 2020a; TOB, 2020b; Cengiz vd., 2007). 2700 yaşında olduğu tahmin edilen dev çınar ağacı, yakınındaki Bizans kalesi'nden daha eski tarihe tanıklık etmiş bir ağaç olarak 28 metrelik boyu, 4.54 metrelik gövde çap1 ve 14.26 metrelik tac1 ile görenlerde hayret uyandırmaktadır.

Ağaç bilgilendirme panosunda Çınar ağacının edebiyattaki simgesel değerine vurgu yapan "Divan, halk, tasavvuf ve çağdaş şiirde adı en sık geçen ağaçlardan biridir çınar. Yapraklarını en geç döken ağaç olması, yapraklarının açılmış bir ele benzemesi, kabuklarının çok ve çabuk soyulması, gövdesinin iri ve diğer ağaçlardan uzun ömürlü olması nedenleriyle edebiyata sık sık konu edinilerek çeşitli anlamlar çıkarılmasına yol açmıştır.

Gövdesinin sslak yapıya sahip olması nedeniyle şimşekleri üzerine çekmesi onun kendi kendine yandığ bir inanca sebebiyet verir. "Yaşlı çınarlar içten çürüyerek dökülür. Son vakte doğru iyice kararır ve yanmış gibi gözükür." Benzeri anlatımlar ve "Bir çınar gördük: Enli, boylu, vakur /Bir ağaç; hiç eğilmemiş, mağrur /Koca bir gövde; belki altı asır, /Belki ondan da fazla, dalgın, ağır” benzeri bir şiirle taçlandırılması ağacın önemini ve akılda yer etmesini sağlayacak bir unsur olarak yararlı olacaktır. Halk edebiyatımızın yabancı turistlere tanıtılması açısından bu tür yaklaşımlar önemlidir.

Ağacın bulunduğu kırsal alanda, doğal ortama zarar vermeyecek nitelikte otopark, ahşap oturma birimleri, köye katkısı olacak hediyelik eşya, yerel ürün satış yeri gibi mekânsal düzenlemelere ihtiyaç duyulmaktadır.

\subsection{Akseki İbradı Yöresi}

Deniz seviyesinden bin metre yüksekte olan İbrad, Antalya'ya 170 kilometre uzakta bir ilçedir. İlçenin yıkılmaya yüz tutmuş yöreye özgü tarihi düğmeli evleri restore ederek turizme kazandırılmıştır. Her yıl binlerce turist İbradı'nın doğal ve kültürel güzelliklerini görmek için ziyaret etmektedir.

\subsubsection{Arapastı Kestanesi}

Antalya Akseki/İbradı'da $19 \mathrm{~m}$ boyunda, $13 \mathrm{~m}$ çevresi olan ağacın 1000-1100 yaşında olduğu tahmin edilmektedir (Şekil 10) (ÇŞB, 2020).

$\mathrm{Bu}$ ünlü kestane ağacının adını yaşanmış bir öyküden aldığı bilinmektedir. İbradı, tarihi boyunca çok büyük yangınlar geçirmiştir. Bu yangınların en önemlilerinden biri, Osmanlı İmparatorluğu'nda da büyük yankı uyandıran 1861 yangınıdır. Bu yangın, Arap köle Zeynep'in, efendisi Mustafa Efendi'nin konağını ateşe vermesiyle başlamış ve İbradı'nın büyük bölümüne yayılarak yanmasına neden olmuştur. Suçlu bulunan Zeynep ise, idam cezasına çarptırılarak bu ağaçta asılmıştır. O günden sonra bu kestane ağacına "Arapastı" adı verilmiştir. Folklorik bir anıt ağaçtır. İlçe merkezine çok yakın kırsal çevredeki ağacın çevresinde ahşap oturma birimleri, bilgilendirme panosu gibi mekânsal düzenlemeler yapılabilir. Ayrıca hediyelik eşya ve geleneksel ürünlerin satıldığı, düğmeli evlere uygun bir satış yeri yapilabilir.
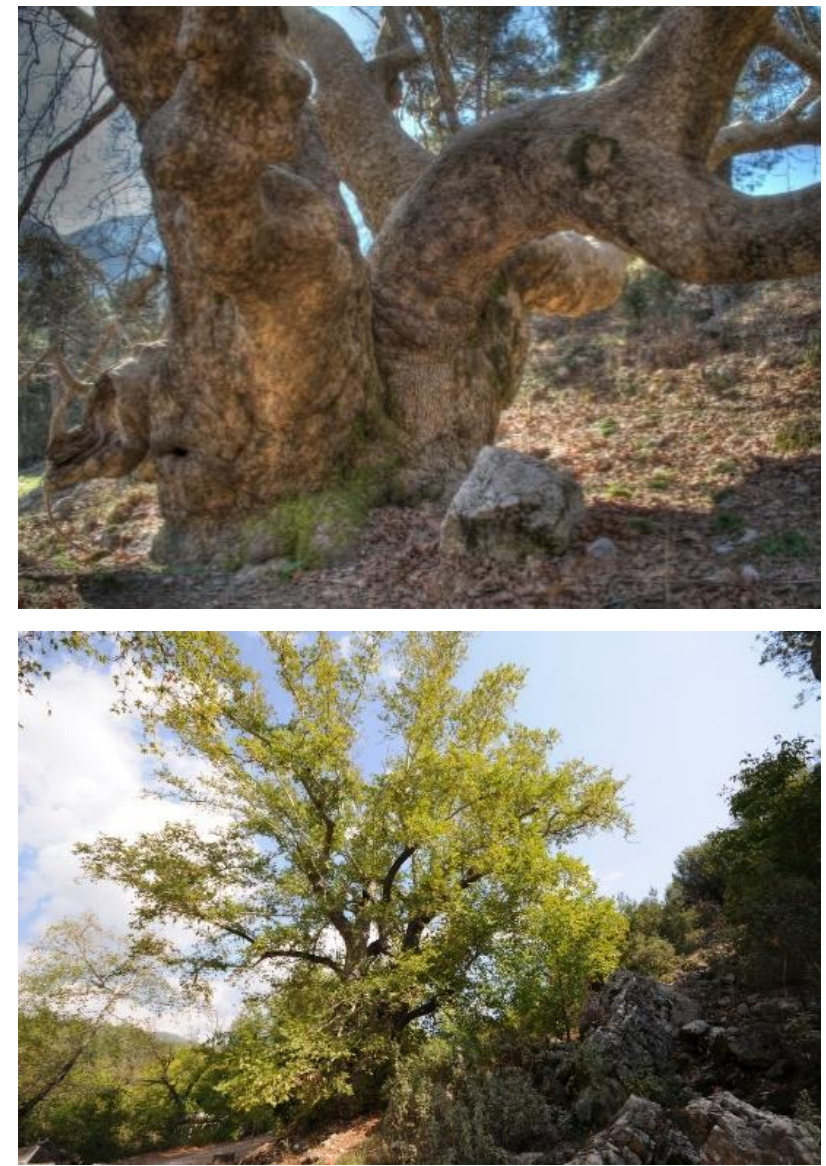

Şekil 9. Antalya ili Kemer ilçesinde bulunan Gedelme Çınarı (Ümit Durak)

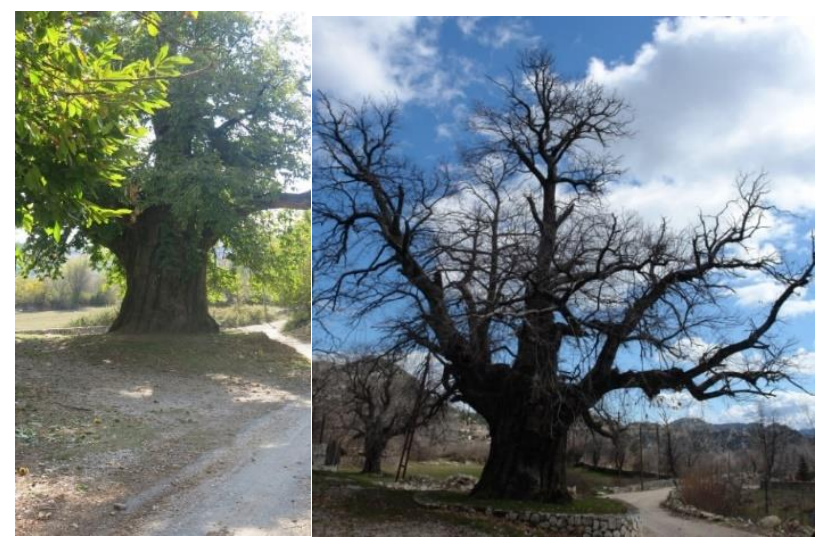

Şekil 10. Antalya ili Akseki/İbradı'da bulunan Arap Astı Kestanesi (Ümit Durak) 


\subsection{Korkuteli Yöresi}

Osmanlı şehzadesi Sultan Korkut'un eğitim gördüğü ve lalalığını burada yaptığı Korkuteli, deniz seviyesinden 1020 metre yüksekte, daha çok karasal iklime sahip bir ilçedir. Halkın genellikle uğraşı alanı tarım, meyvecilik, hayvancılık ve arıcılık ile orman işçiliğidir. Bölgede son yıllarda yaygınlaşan kültür mantarı üretimi de ilçe ekonomisine büyük katkılar sağlamaktadır.

\subsubsection{Doğu Çınarı (Platanus orientalis)}

Antalya-Korkuteli ilçesinde 3 adet Platanus orientalis türüne ait boyutsal anıt ağaç vardır. İlki 1001 yaşında, $70 \mathrm{~cm}$ gövde çapı, $8 \mathrm{~m}$ tepe çapına sahip ve 20 metre boyundadır. İkincisi 950 yaşında $80 \mathrm{~cm}$ gövde çapı, 7 metre tepe tacı, 19 metre boyunda ve üçüncüsü 700 yaşında $170 \mathrm{~cm}$ gövde çap1, $7 \mathrm{~m}$ tepe çapı ve yaklaşık $20 \mathrm{~m}$ boyundadır (Şekil 11) (ÇŞB, 2020). Ağaçlar kent merkezindedir.

Yol kenarında beton, asfalt gibi geçirimsiz malzeme ile çevrili bu ağaçların kök boğazı çevreleri geçirimsiz malzemelerden arındırıldıktan sonra, gübre ile zenginleştirilmiş toprak harçla doldurularak ağaç sağlığ1 iyileştirilmelidir. 700 yaşındaki Doğu Çınarının Alâeddin Keykubat Caddesi üzerinde orta refüjde yer alması dikkat çekicidir. Cadde üzerindeki konumundan dolayı yakında yer alan okuldaki orta öğretim öğrencileri için eğitim öğretim faaliyetlerinde farkındalık oluşturma amaçlı kullanımında anıt ağacın konumu tehlike oluşturabilir. Bu nedenle ağaç ile ilgili bilgileri daha güvenli bir şekilde karşı yolun kenarında yaya kaldırımında da konumlandırmak yararlı olacaktır. Olanak dahilinde araç yolunu ağaçtan uzak bir şekilde planlayıp ağaç çevresinde bir yaya mekanı düzenlemek de mümkün olabilir.

Ağaçlara dikkat çekmek için ağaç için hazırlanacak panoda çınarın mitolojik hikayesine yer verilebilir. Bu hikaye şöyledir: "Yunan ve Roma mitolojisindeki efsaneye göre Baukis ve Philemon, Frigya dolaylarındaki bir kentte yaşayan yoksul ve yaşlı bir çifttir. Bir gün Tanrı Zeus ve oğlu Hermes, Olympos dağından inerek insan kılığına bürünür ve halkın arasına karışırlar. Kimi kaynaklara göre bugünkü Bergama, kimine göre ise Kapadokya civarına gelen iki tanrı burada gördüklerinden hiç hoşlanmadıkları gibi, kalacak yer istedikleri hiçbir ev sahibi tarafından da misafir olarak kabul edilmezler. Sinirlenen tanrılar, en son şanslarını Baukis ve Philemon'un kapısını çalarak dener. Basit bir kulübede yaşayan yaşlı çift iki adamı kabul eder ve tüm yoksulluklarına rağmen son derece cömert davranırlar. Misafirlerine şarap ve yemek ikram eden Baukis, bir an farkeder ki, görünmez bir bereket sayesinde iki adam yiyip içtikçe sofradan hiçbir şey eksilmiyordur! O an yaşlı çift iki adamın tanrı olduğunu anlar ve herhangi bir hata yaptılarsa kendilerini bağışlamalarını isterler. Zeus buna gerek olmadığını, evlerini onlarla beraber terk etmelerini söyler. Çünkü konukseverlik göstermeyen herkesi ve kasabayı yok edecektir. Bunun üzerine Tanrılarla beraber dağın zirvesine çıkan yaşlı çift, kasabanın sular altında kaldığını görür; fakat kendi kaldıkları kulübe, artık gösterişli bir tapınağa dönüşmüştür. Zeus yaşlı çifte bir şey isteyip istemediklerini sorar. Yaşamdan pek bir beklentisi olmayan karı-koca, tapınağın bekçisi olmayı ve en önemlisi birbirlerinden hiç ayrılmamayı, vakti geldiğinde beraber ölmek istediklerini söyler. Zeus bu isteği yerine getirecektir. Ölüm vakti geldiğinde birbirini çok seven bu yaşlı karı koca, iç içe geçen iki farklı ağaca dönüşür. Derler ki; onlar artık aynı gövdede birleşen çınar ve ıhlamur ağacı olmuştur." (Zimba, 2021).

$\mathrm{Bu}$ hikayeler bir yandan hikayeleri sevenlere ağaç ve doğa sevgisi aşılarken, diğer yandan ağaç ve doğa severlere mitoloji ve edebiyata ilgiyi oluşturabilecektir.

\subsection{Anıt ăgaçların mekansal özellikleri}

Anıt ağaçların mekânsal özellikleri değerlendirildiğinde yukarıda her ağaç özelinde ele alındığımız konulara ek olarak bütüncül bir özet değerlendirme yapılarak Çizelge 1'de sunulmuştur.

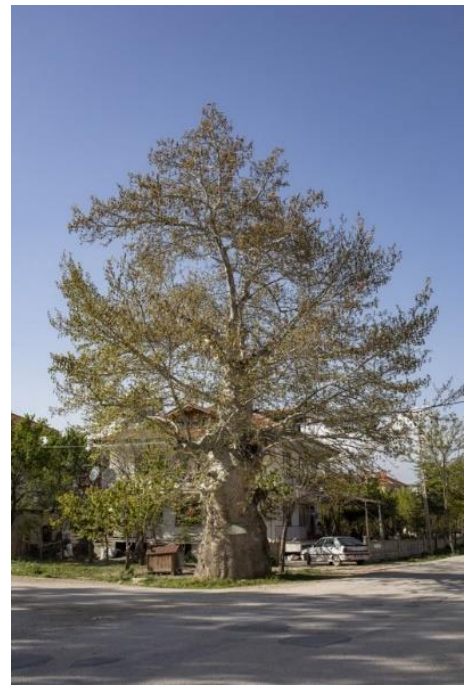

(a)

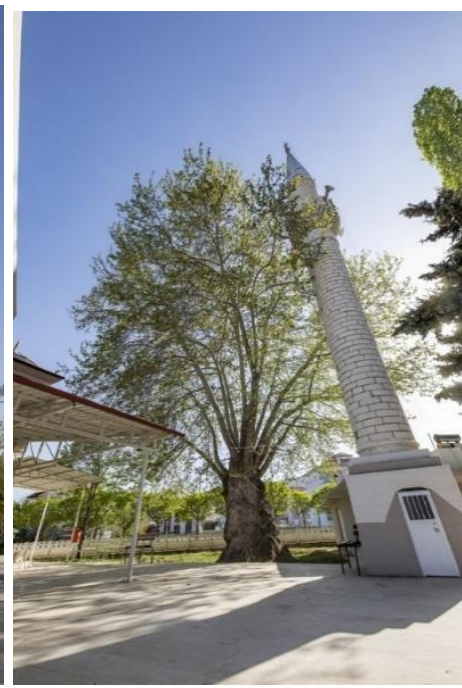

(b)

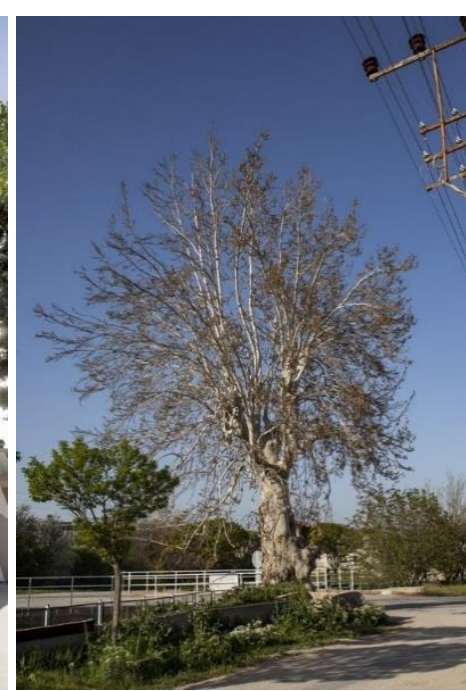

(c)

Şekil 11. Korkuteli İlçesi'ndeki anıt ağaçlar (ÇŞB, 2020). 
Çizelge 1. Antalya ilinde çalışma kapsamında ele alınan anıt ağaçların mekânsal özellikleri

\begin{tabular}{|c|c|c|c|c|c|c|}
\hline Anıt Ağaç & Konum & Erişilebilirlik & Güvenlik & Donatı varlığ1 & Görsel kalite & Çevre ile ilişki \\
\hline Aslan Ardıç & Çı̆̆lıkara *TKA & Rehber eşliğinde & Güvenli & Tabela & Çok iyi & Orman \\
\hline Toros Sediri & Çığlıkara TKA & Rehber eşliğinde & Güvenli & Tabela & Çok iyi & Orman \\
\hline Koca Sedir & Elmall $* *$ SAO & Bireysel erişime uygun & Güvenli & Tabela & Çok iyi & Orman \\
\hline Şah Ardıç & Elmalı SAO & Bireysel erişime uygun & Güvenli & Tabela & Çok iyi & Orman \\
\hline Koç Sedir & Çığlıkara TKA & Rehber eşliğinde & Güvenli & Tabela & Çok iyi & Orman \\
\hline Katil Sedir & Çığlıkara TKA & Rehber eşliğinde & Güvenli & Tabela & Çok iyi & Orman \\
\hline Koca Katran & Çı̆̆lıkara TKA & Rehber eşliğinde & Güvenli & Tabela & Çok iyi & Orman \\
\hline Lübnan Sediri & Kızılağaç- Gedik Çukuru & Bireysel erişime uygun & Güvenli & Tabela & Çok iyi & Orman \\
\hline Ambar Katran & Dibek TKA & Rehber eşliğinde & Güvenli & Tabela & Çok iyi & Orman \\
\hline Gedelme Çınarı & Gedelme Yaylası & Bireysel erişime uygun & Güvenli & Tabela & Çok iyi & Kirsal \\
\hline Arapastı Kestanesi & İbradı ilçe merkezi & Bireysel erişime uygun & Güvenli & Tabela & İyi & Kirsal \\
\hline Doğu Çınarı 1 & Korkuteli Alladdin Keykubat Caddesi & Bireysel erişime uygun & Araç trafiği & Yok & Orta & Orta refüj \\
\hline Doğu Çınarı 2 & Korkuteli merkez & Bireysel erişime uygun & Güvenli & Pergola, bank & Orta & Cami bahçesi \\
\hline Doğu Çınarı 3 & Korkuteli merkez & Bireysel erişime uygun & Araç trafiği & Yok & Orta & Yol kenarı \\
\hline
\end{tabular}

*TKA: Tabiatı Koruma Alanı, **SAO: Sedir Araştırma Ormanı

\section{Sonuç ve öneriler}

Toplumun ortak mirası olup geçmişle günümüz arasında bağ kuran anıt ağaçların korunabilmesi, bunların ancak topluma mal edilmesiyle mümkündür. $\mathrm{Bu}$ bağlamda anıt ağaçların tespit ve tescili önemlidir. Anıt ağaç tespit ve tescil işlerinde çalıştırmak üzere, ilgili birimlerde görevlendirilecek kişiler, bu konunun uzmanı (bu konuda lisans üstü eğitim almış) orman mühendisleri, ziraat mühendisleri, peyzaj mimarları veya biyologlar arasından seçilmelidir (Genç ve Güner, 2001).

Anıt ağaçların sağlıklı ortam koşullarının sürdürülebilirliği sağlanmalıdır. Ortam değişiklikleri ve kötüleşen zemin koşulları, komşu ağaçların yarattığı olumsuzluklar, ziyaretçi etkileri gibi baskılara maruz kalan ağaçlarda koruma ve doğru bakım kararlarının belirlenmesi büyük önem taşır. Bu gibi durumlarda bir ağacın iyi bir performans göstermesi; baskıların toplam şiddeti, tür, yaş ve baskı altında yaşama direnci gibi faktörlere bağlıdır.

Anıt ağaçların arborikültürel ilkeler temelinde tek ağaç bakımlarına önem verilmesi gerekir. Bu kapsamda budama, seyreltme ve ağaç cerrahisi çalışmaları ön plana çıkmaktadır. Söz konusu ağaçlarda uygulanacak budamaların genel prensipleri şu şekilde açıklanabilir: Budamalarda; kuru ana dalların uzaklaştırılması, mekanik direnci azalmış olan ana dal ve dalların uzaklaştırılması, kısaltılması ya da yükünün azaltılması, tepe tacından ayrı gelişmiş ana dalların uzaklaştırılması, tepe tacının ve dalsız gövde kitlesinin biçimlenmesi ve görsel bir bütünlük sağlanmasına dönük dengeleme budamaları, ana dallar üzerinde de; kuru, sıkışı, anormal gelişim gösteren, ana dalların direncini azaltan ve tepe tacının simetrisini bozan dalların uzaklaştırılması temel teknik prensipler kabul edilmelidir (Dirik, 2014; Dirik vd., 2014).

Budamalar, dallar arasındaki ilişkilerin ve gelişme kusurlarının daha net görülebileceği yaprakların dökülmüş olduğu dönemlerde yapılmalıdır. Budama uygulamalarından sonra yara yüzeylerinin yara macunları ile kapatılması ve kallus gelişimine göre bu uygulamanın 6 ayda bir tekrar edilmesi çürükçül mantar ataklarının önlenmesi bakımından ihmal edilmemelidir. Budamalar esnasında ayrıca söz konusu ağaçları sıkıştıran ve gelişimini zorlaştıran yakın konumlu diğer ağaçlarda taç küçültme ve kısaltma budamalarına başvurulmalıdır.

Anıt ağaçları gelecek nesillere aktarmak için bugün onları tespiti ve korunması oldukça önemlidir. Antalya'da olduğu gibi birçok ilimizde tescilli olmadığı için anıt ağaç niteliği kazanmamış, varlığından habersiz olduğumuz anıt ağaçlarımız vardır. $\mathrm{Bu}$ nedenle bu ağaçlar için gereken bakım-koruma tedbirleri alınamamaktadır. $\mathrm{Bu}$ konu daha fazla önemsenmeli ve anıt ağaç niteliğindeki türler 24 Ekim 2020 tarih ve 31284 sayılı Resmi Gazetede yayınlanan Çevre ve Şehircilik Bakanlığı'nın “Tabiat Varlıklarını Koruma Merkez Komisyonunun, Tabiat Varlığı Olarak Belirlenecek Anıt Ağaçların Tespitine İlişkin İlke Kararı (No: 110)" dikkate alınarak kayıt altına alınmalıdır.

Anıt ağaçların önüne yerleştirilen tabelalarda ağacın adı, ağaç hakkında bilgi ve QR kodu verilerek ağaç hakkında bilgilendirme oldukça yararlı bir teknik olarak kullanılmaktadır. QR kodu akıllı telefon, tablet gibi araçlarla okutulduğunda yazılı ya da sesli olarak ağacın dilinden yaşı, türü, ana vatanı, yaprak ve kök özellikleri ve hikâyesi hakkında bilgilere ulaşılabilir.

Büyüleyici etkileriyle anıt ağaçlar, yetişkinlerde olduğundan daha fazla çocuk ve gençlerde doğa ve ağaç sevgisini artırmak için öneli kaynaklar niteliğindedir. Antalya'da kırsal alanda bulunan bu anıt ağaçlara düzenlenecek bilimsel nitelikli geziler öğrenciler için oldukça yararlı olabilir. Bu ağaçların çevresinde yapılacak doğa ile uyumlu mekânsal düzenlemeler ile ağaçların aktivitelerden olumsuz etkilenmesi önlenebilirken, çevrede konumlandırılacak bilgilendirme panoları, uzmanlar tarafından oluşturulmuş doğru istikametteki patikalar anıt ağaçların sosyo-kültürel anlamda topluma ve eğitime olan katkısını sağlamak için birer araç olabilir. Mekansal organizasyonu kırsal etki ile bütünleşik bir şekilde tasarlamak, mekanın kullanıcı üzerindeki olumlu etkisini artıracak, doğayla uyumu insan ölçeğinde mümkün kılacaktır. $\mathrm{Bu}$ anlamda fikir oluşturabilecek örnek uygulamalar Şekil 12 (a, b, c, d, e, f)'de sunulmuştur. 


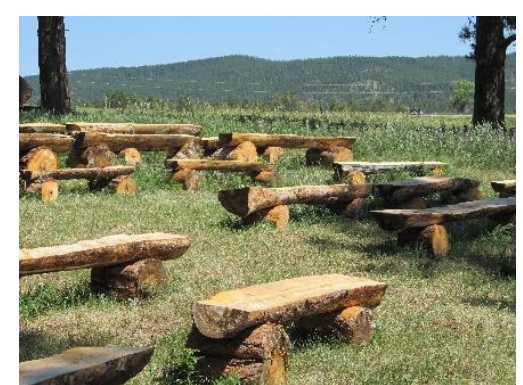

(a) (Kaynak: Miguel, 2021)

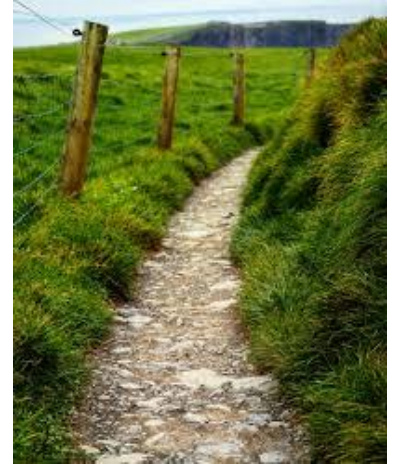

(d) (Kaynak: Pxhere, 2021)

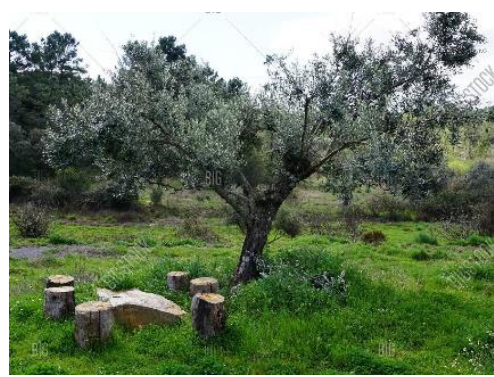

(b) (Kaynak: Dreamstime, 2021)

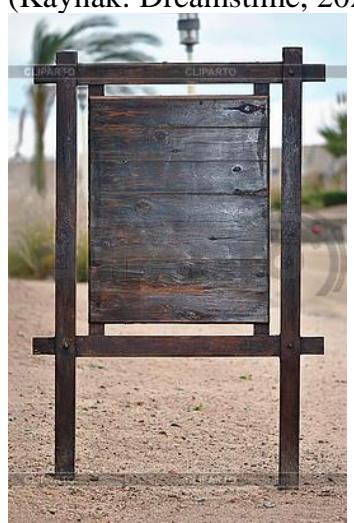

(e) (Kaynak: Pixers, 2021)

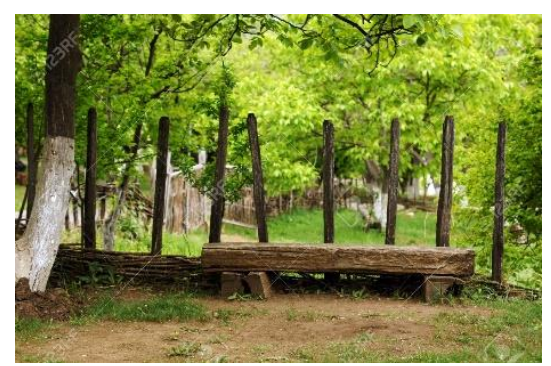

(c) (Kaynak: Bogush, 2021)

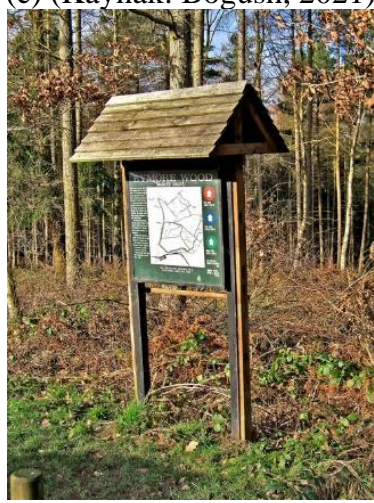

(f) (Kaynak: Chadwick, 2008)

Şekil 11. Anıt ağaçlar çevresinde tasarlanabilecek oturma alanları (a, b ve c), patikalar (d) ve bilgilendirme panolarına (e ve f) örnekler

\section{Kaynaklar}

Acar, İ., 2015. Kızılağaç’ta bir doğa anıtı: Lübnan sediri, Antalya Kültür ve Turizm Dergisi, Y11:5 Sayı:29, s.96

Asan, Ü., 1991. Doğal ve Kültürel Miraslarımızdan Anıt Ağaç ve Ormanlarımız. Yeşile Çerçeve, 6: 22-24.

Asan, Ü., 1993. Mistik ve Folklorik Yönüyle Anıt Ağaçlarımız. Yesile Cerçeve, 23: 13-15.

Asan, Ü., 2010. İstanbul'un Doğal Mirası Anıt Ağaçlar, İBB. Kültür Yayınları, İstanbul.

Albian, N., Berwick, C., 2004. Forêt et religion au Japon: d'une vision singulière de l'arbre à une gestion particulière de la forêt. Revue Forestière Française. 56(6): 563-572.

Bayar, E., Türker, H., Genç, M., 2012. Gölhisar-Burdur Anıt Ağaçları: Göller Bölgesi Anıt Ağaç Varlığına Yeni İlaveler. Bartın Orman Fakültesi Dergisi, 14(22): 83-95.

Baytop, A., 2003. Türkiye'de Botanik Tarihi Araştırmaları. Çetin Matbaac1lk, İstanbul.

Bogush, A, 2021. Ahşap oturma bankı örneği, garden bench in rural landscape, https://www.123rf.com/photo_14879747_gardenbench-in-rural-landscape.html

Bernabei, M., 2015. The age of the olive trees in the Garden of Gethsemane. Journal of Archaeological Science, 53: 43-48.

Chadwick, P. L., 2008. Information Board, Eymore Wood / CC BYSA 2.0, Ahşap bilgilendirme panosu örneği.

Cihanger, D., 2013. Trees In The Urban Context: A Study On The Relationship Between Meaning and Design. Master Thesis, The Graduate School Of Natural and Applied Sciences Of Middle East Technical University, Ankara.

Cengiz, Y., Başaran, M.A., Işık, K. 2007. 20. Yüzyılda Antalya'da Ormanlar, Ormanc1lık ve Korunan Alanlar. 20. Yüzyılda Antalya Sempozyumu, 22-24 Kasim 2007, Antalya, s. 550-609.

Crews, J., 2003. Le symbolisme de la forêt et des arbres dans le folklore. Perception des forêts. Unasylva, 213(54): 37- 43.

ÇŞB, 2020. Anıt Ağaçlar, Çevre ve Şehircilik Bakanlığı, https://www.anitagaclar.gov.tr., Erişim: 07.01.2021.
Dreamstime, 2021 Ahşap oturma bank1 örneği. ID: 166103572. https://www.dreamstime.com/image-green-farm-landscapeolive-tree-handmade-wooden-table-benches-image 166103572, Erişim: 27.08.2021.

Garcia, C., Pascal, J-P., Kusgalappa, C.G., 2006. Les forêts sacrées du Kodagu en Inde: Écologie et religion. Bois et Forêts des Tropiques, 288: 5-13.

Genç, M., Güner, Ş.T., 2001. Anıt Ağaç Envanteri ve Seçimi İçin Yeni Bir Yöntem. I. Ulusal Ormanc1lık Kongresi Bildiriler Kitab1, 19-20 Mart 2001, Ankara, 234-251.

Dirik, H., Erdoğan, R., Altınçekiç, H.S., Altıçekiç, S., 2014. Kent Ağaçlarının İşlevleri, Koruma Önemi ve Değer Belirleme Yaklaşımları. Artvin Çoruh Üniversitesi Orman Fakültesi Dergisi, 15(2): 161-174.

Dirik, H., 2014. Arborikültür (Kentsel Ağaç Kültürü), İstanbul Üniversitesi Orman Fakültesi Yayın No:5200, Orman Fakültesi Yayın No:509, İstanbul, s.566.

Kantarc1, D., 1984. Türkiye'de En Yaşlı Sedir Ağacı -Ambar Katran, İstanbul Üniversitesi Orman Fakültesi Dergisi, Cilt, 34, Sayı:2, s. $49-58$

KTB, 2020. Antalya İl Kütür Turizm Müdürlügüu, Kültür ve Turizm Bakanlığı https://antalya.ktb.gov.tr/TR-67914/dogalguzellikleri.html, Erişim: 10.01.2021.

Miguel, D., 2021. 40+ Extraordinary Outdoor Bench Projects, DIY Projects.https://i.pinimg.com/originals/dd/d5/f6/ddd5f64931f9d 93a5b0ad999fcfed62a.jpg Erişim: 27.08.2021.

Musselman, L.J., 2003. Les arbres dans le Coran et la Bible. Perception des forêts Unasylva, 213(54): 45-52.

Pardo, C., 2005. Du rural à l'urbain. Intégrations, usages et gestions de l'arbre dans les paysages de la méditerranée nordoccidentale. Thèse presentée à l'Université Paul Valery Montpellier III Arts et Lettres, Langues et Sciences Humaines et Sociales UFR III. Département de Géographie et d'Aménagement pour obtenir le grade de docteur spécialité: Géographie, Soutenue le: Décembre 2005., 606 p.

Pixers, 2021. Ahşap bilgilendirme panosu örneği, https://pixers.pl/plakaty/drewniana-tablica-informacyjna36976401, Erişim: 27.08.2021. 
Pxhere, 2021. Yürüyüs patikas1, örneği, https://pxhere.com/ es/photo/165725, Erişim: 27.08.2021.

Sène, E.H., 2003. Arbres, forêts, croyances et religions en Afrique de l'Ouest Sahélienne. Perceptions des forêts. Unasylva 54(213):44

Swamy., P.S., Kumar, M., Sundarapandian, S.M., 2003. Spirtualité et écologie des bois sacrés au Tamil Nadu, Inde. Perception des forêts. Unasylva, 54(213): 53-58.

TOB, 2020a. Antalya Milli Parklar Şube Müdürlügü Arşiv Kayıtları, Tarım ve Orman Bakanlığı, Antalya.
TOB, 2020b. İstatistikler, Tarım ve Orman Bakanlığ 1 , Ankara, https://www.tarimorman.gov.tr/DKMP/Belgeler/dkm p/resmiistatistikler/korunanalanistatistikleri/2017/istatistikitabl olar/tabiataniti.xls, Erişim: 05.01.2021.

Tez, Z., 2008. Biyolojinin Kültürel Tarihi. Doruk Yayınları ISBN: 978-975-553-487-9, İstanbul.

Zımba, A., 2021. https://www.haberler.com/cinar-agaci-ozelliklerineler-cinar-yapragi-12717780-haberi/. Erişim: 10.01.2021. 